\title{
Tissue Processing: Role of Secondary Sterilization Techniques
}

\author{
Frederick M. Azar, MD
}

\section{KEYWORDS}

- Allograft • Musculoskeletal • Sterilization

The use of allografts in sports medicine surgery has been steadily increasing over the past 10 to 15 years as long-term reports have shown that results with musculoskeletal allografts approach those with autografts. ${ }^{1-4}$ The use of musculoskeletal allografts from the American Association of Tissue Banks (AATB) accredited tissue banks increased from 337,338 in 1996 to $1,279,000$ in 2003 (Table 1). ${ }^{5}$ Each year approximately 1.5 million bone and tissue allografts are implanted in the United States, of which approximately $10 \%$ are soft-tissue grafts, most commonly bone-patellar tendon-bone (BPTB), Achilles tendon (Fig. 1), fascia lata, anterior and posterior tibial tendon (Fig. 2), quadriceps and hamstring tendon, and menisci. ${ }^{6,7}$ A 2006 member survey by the American Orthopaedic Society for Sports Medicine (AOSSM) indicated that $86 \%$ used allografts in knee reconstructive procedures; ${ }^{8,9}$ however, despite this widespread use, a substantial number of surgeons expressed concerns about the risk of disease transmission and infection with allografts. A number of advantages of allografts over autografts have been cited, including no donor-site morbidity, shorter operative time, smaller incisions, and greater availability, but all of these have been overshadowed by the most frequently cited disadvantage: risk of disease transmission. ${ }^{10-12}$ Recent reports of serious infections associated with allografts have heightened these concerns. ${ }^{13-15}$ Of 26 bacterial infections associated with allografts reported to the Centers for Disease Control and Prevention (CDC), 70\% were in patients who had anterior cruciate ligament (ACL) reconstructions. ${ }^{13,14}$ A 2004 report $^{16}$ indicated that of the 875,000 musculoskeletal allografts distributed in 2001 , clostridium infections occurred in $0.12 \%$ of all sports medicine tissues (tendons, menisci, and femoral condyles).

\footnotetext{
University of Tennessee-Campbell Clinic Department of Orthopaedic Surgery, 1211 Union Avenue, Suite 520, Memphis, TN 38104, USA

E-mail address: fazar@campbellclinic.com
} 


\begin{tabular}{|c|c|c|}
\hline \multicolumn{3}{|c|}{$\begin{array}{l}\text { Table } 1 \\
\text { Donors and distribution from AATB-accredited tissue banks }\end{array}$} \\
\hline Year & No. of Donors & $\begin{array}{l}\text { Musculoskeletal Tissue } \\
\text { Allografts Distributed }\end{array}$ \\
\hline 1996 & 17,010 & 337,338 \\
\hline 2001 & 20,490 & 710,064 \\
\hline 2003 & 23,295 & $1,279,000$ \\
\hline
\end{tabular}

Data from Vangsness CT Jr. How safe are soft-tissue allografts? AAOS Now, August 2007. Available at: http://www.aaos.org/news/bulletin/aug07/clinical1.asp.

\section{RISK OF DISEASE TRANSMISSION FROM MUSCULOSKELETAL ALLOGRAFTS}

Donor screening and testing (Table 2) can reduce the possibility of disease transmission, but a "window" period still exists during which a donor with an active viral infection may not have any detectable viral antibodies or antigens. ${ }^{17}$ With nucleic acid testing (NAT), this window is approximately 7 days for human immunodeficiency virus (HIV) and hepatitis- $\mathrm{C}$ virus $(\mathrm{HCV})$ and about 8 days for hepatitis- $\mathrm{B}$ virus (HBV). ${ }^{18}$ Currently, the risk of transplanting tissue from an HIV-infected donor is estimated to be 1 in $1.6 \mathrm{mil}-$ lion. ${ }^{11,19-21}$ Because of the greater prevalence of hepatitis in the general population, estimated to be 1.2 million infected with $\mathrm{HBV}$ and 3.9 million with $\mathrm{HCV},{ }^{17}$ the risk of the transmission of HBV or HCV is greater than that of HIV. The risk of contracting HCV from unprocessed tissue that is NAT HCV negative is estimated to be 1 in $421,000 .^{21}$ McAllister and colleagues ${ }^{9}$ noted that the current risk of an allograft-transmitted infection appears to be much less than the overall risk of perioperative nosocomial infection.

More recently, emerging pathogens have become a concern in the use of allograft material. Little information exists about the potential threat from such entities as West Nile virus, severe acute respiratory syndrome (SARS) coronavirus, and prion disease associated with transmissible spongiform encephalopathies such as CreutzfeldtJakob disease (CJD) and its variants. Between 1985 and 2002, 97 occurrences of CJD were reported in Japanese patients who had received dura mater allografts; the rate of infection declined after improved processing procedures were introduced in $1987 . .^{22}$ No prion-disease transmission has been reported in association with musculoskeletal allografts, and the risk of acquiring these diseases as the result of

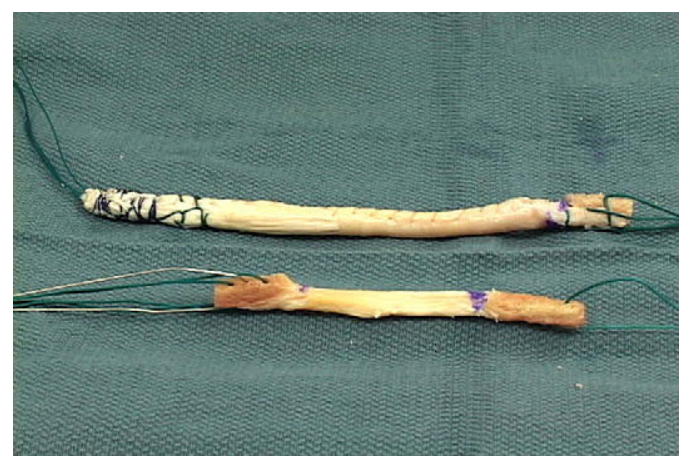

Fig.1. Commonly used allografts in knee surgery. Top, Achilles tendon graft used for reconstruction of the posterior cruciate ligament. Bottom, Bone-patellar tendon-bone graft used for reconstruction of the anterior cruciate ligament. 


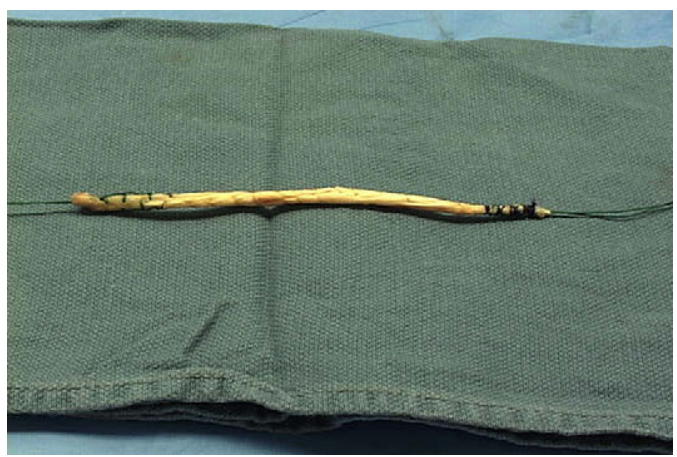

Fig. 2. Tibialis allograft.

Table 2

Process of allograft procurement, sterilization, and storage

Donor screening

Precluded by history of autoimmune disease Ingestion or exposure to toxic substances Rheumatoid arthritis

Systemic lupus erythematosus

Polyarteritis nodosa

Sarcoidosis

Clinically significant bone disease

Blood testing must be negative for antibodies to HIV

Nucleic acid test (NAT) for HIV-1

Hepatitis B surface antigen

Total antibody to hepatitis B core antigen,

Antibodies to hepatitis $\mathrm{C}$ virus (HCV)

NAT for HCV

Antibodies to human T-lymphotropic virus

Syphilis

Tissue harvest

Within $24 \mathrm{~h}$ of death if body cooled

Within $15 \mathrm{~h}$ of death if body not cooled

Aseptic technique

Tissue cultured before processing

Disinfection: removal of contaminants

Secondary sterilization: destruction of all life forms

Antibiotic soaks

Ethyl oxide, other chemical sterilants

Gamma/electron-beam irradiation

Proprietary protocols (ie, Allowash, BioClense, Clearant)

Storage

Fresh-freezing (3-5 y)

Cryopreservation (up to $10 \mathrm{y}$ )

Lypophilization ( $3-5$ y at room temperature) 
a musculoskeletal allograft is unknown, although it is likely extremely low because of the rarity of these diseases in the general population. ${ }^{9}$

\section{OVERSIGHT OF PREPARATION OF MUSCULOSKELETAL ALLOGRAFTS}

In the United States,oversight of tissue banks takes place at 3 levels: the American Association of Tissue Banks (AATB), the Food and Drug Administration (FDA), and state agencies. ${ }^{6}$ The AATB has developed standards for tissue banking, and it accredits tissue banks but has no power to shut down a tissue bank, fine or imprison its operators, or order the retention or destruction of tissue that does not comply with minimal requirements. ${ }^{6}$ The FDA does have that power, but one of their limitations is that registration of tissue banks has not been required, making it difficult for the FDA to identify and inspect such entities. ${ }^{23,24}$ Only a small percentage of tissue banks are AATB-accredited, and few states require tissue banks to be licensed. In 2005, the FDA set up 3 new regulations for entities involved in human tissue products: "registration" rules for tissue banking institutions, "donor eligibility" rules that provide criteria for donor screening and selection, and "current good tissue practices" rules that concern tissue procurement, processing, and distribution. ${ }^{25}$ Currently, there is more federal oversight of tissue banks and improved donor screening and testing techniques, including the use of NAT. In the United States, all establishments that collect, process, or handle human cells, tissues, and cellular or tissue-based products must now register with the FDA.

\section{DECREASING THE RISK OF DISEASE TRANSMISSION BY MUSCULOSKELETAL ALLOGRAFTS}

The FDA does not require that tissues undergo sterilization nor does it require that recovery and processing of tissues be done in an aseptic manner, both of which are essential to improving allograft safety. ${ }^{24}$ Sterilization of musculoskeletal tissues has several inherent problems: the biomechanical integrity of the tissue can be substantially altered by heat and irradiation, not all sterilizing agents have adequate tissue penetration, and musculoskeletal tissues are often contaminated with a large number of organisms.

\section{Aseptic Procurement}

Aseptic procurement is a fairly standardized procedure in which standard sterile operating room techniques are used, including using gowns, gloves, and sterile instruments. Aseptically processed tissues, however, should not be considered sterile. ${ }^{26}$ Contamination from health care personnel or from the donor (gastrointestinal or respiratory tract) may not be eliminated or even adequately reduced by soaking in antibiotic solution, as is done in most tissue banks to reduce the surface contamination (bioburden) of the allograft tissue. Although culturing of allograft tissue is commonly done to check for the presence of bacteria and fungi after soaking, studies have shown that cultures are, at best, only $78 \%$ to $92 \%$ sensitive. $^{27}$

\section{Disinfection and Secondary Sterilization}

Disinfection-removal of contaminants from the tissue-should not be mistaken for sterilization-destruction of all forms of life, especially microorganisms. Sterility is expressed as a mathematic probability of relative risk. The FDA considers a sterility assurance level (SAL) of $10^{-3}$ (1 in 1,000 chance that a nonviral viable microbe exists) adequate for implantable biologic medical devices. ${ }^{24}$ The AATB requires an SAL of $10^{-6}$ (less than a 1 in 1,000,000 possibility of a contaminating organism) for tissue bank allografts. ${ }^{28}$ Unlike surgical instruments and equipment, it is practically 
impossible to absolutely sterilize human tissue without compromising the biomechanical properties or biocompatibility of these tissues. For example, heat and high doses of radiation ( $>3.0 \mathrm{Mrad}$ ) can effectively provide an SAL of $10^{-6}$, but both can weaken the collagen structure of the allograft. ${ }^{29,30}$

\section{Chemical sterilization}

Chemical sterilization agents have included peracetic acid (PAA), ethylene oxide, hydrogen peroxide, supercritical carbon dioxide, beta-propiolactone, and glutaraldehyde; the last 2 are no longer used because of their toxicity, and the others are generally used in combination with other methods of sterilization.

Ethylene oxide, commonly used for sterilizing medical devices, was one of the first methods used to sterilize allografts. ${ }^{31}$ Chemical residues left by the sterilization process, however, were suggested to cause intra-articular reactions with chronic synovitis, graft failure, and bone dissolution. ${ }^{32,33}$ Ethylene oxide has been reported to have some carcinogenic effects in workers exposed to it, ${ }^{34}$ but there is no evidence that allografts sterilized with ethylene oxide have induced cancer. ${ }^{20}$ In patellar tendon grafts, ethylene oxide can cause a foreign body reaction that results in dissolution of the graft, $32,33,35$ termed the "applesauce reaction" by Arnoczky because of the appearance of the dissolved graft. ${ }^{36}$ This sterilization method is rarely used today.

PAA has been used since the early 1980s, mainly to sterilize bone allografts. Several preliminary in vitro studies suggested that it produced no adverse effects on the structural and mechanical properties of treated bone grafts. ${ }^{37,38}$ Analyses of the mechanical function of BPTB grafts in vitro revealed no adverse effects of PAA sterilization compared with unsterilized grafts. ${ }^{39} \mathrm{~A}$ more recent study, ${ }^{40}$ however, found in a goat model that PAA sterilization delayed or partially inhibited the biological remodeling of PAA grafts, leading to impaired functional knee stability and reduced structural properties of the graft during subsequent healing up to 3 months. The authors recommend caution when considering PAA-sterilized allografts for ACL reconstruction.

\section{Radiation sterilization}

Gamma irradiation has been shown to be effective for sterilization of allograft tissues, killing bacteria at doses of 1.5 to $2.6 \mathrm{Mrad} ;{ }^{4}$ higher doses (>3.5 Mrad) are necessary to kill viruses. ${ }^{29,30,41}$ Fideler and colleagues ${ }^{29}$ found that some HIV-infected bone-tendon-bone allografts remained positive for the virus after 2.5 Mrad of irradiation and recommended that grafts be exposed to levels as high as 3.6 to 4 Mrad. Heat and high doses of radiation (>3.0 Mrad) can produce an SAL of $10^{-6}$, but such high doses substantially affect the biomechanical properties of allografts. ${ }^{29,30,42,43}$

The effects of lower levels of irradiation on allografts remain an area of controversy. ${ }^{44,45}$ Schwartz and colleagues ${ }^{45}$ confirmed in a goat model that 4.0 Mrad caused $30 \%$ and $21 \%$ reductions in stiffness and maximal force, respectively, at 6 months after implantation. Even low-dose irradiation (2 Mrad, $20 \mathrm{kGy}$ ) has been shown to diminish the strength and increase the cyclic elongation of BPTB allografts. ${ }^{46}$ Balsly and colleagues, ${ }^{47}$ however, tested bone grafts (dowel and iliac crest wedge grafts) and soft-tissue grafts (patellar, anterior tibial, and semitendinosus tendons and fascia lata) exposed to low-dose (18.3-21.8 kGy) or moderate-dose (24.0-28.5 kGy) gamma irradiation and found no statistically significant differences in mechanical strength or modulus of elasticity for any graft irradiated at low-dose compared with controls. Bone allografts and 2 of the soft-tissue allografts (anterior tibial and semitendinosus tendons) demonstrated strength and modulus of elasticity values similar to those of controls. 
Electron-beam radiation has been used for sterilization, primarily of soft-tissue grafts, because of its lower penetrability ( $8 \mathrm{~cm}$ through the density of water) compared with gamma irradiation (30 $\mathrm{cm}$ through the density of water), which would be a problem with cortical bone allografts, which have a density of about twice that of water. ${ }^{48,49}$ The advantage to electron-beam irradiation is higher processing speed-seconds, compared with hours for gamma irradiation. Although one biomechanical cadaver study of electron-beam radiation combined with tissue-protective measures (low temperature, carbon dioxide) concluded that the process did not impair the mechanical properties of BPTB grafts, ${ }^{50}$ another determined that both gamma and electronbeam irradiation caused reductions in tensile strength, elastic modulus, strain, and toughness of rabbit tendons. ${ }^{49}$ The decreases in strength and toughness were dose-dependent: the average loss of tensile strength was $36 \%$ with $25 \mathrm{kGy}$ and $55 \%$ with $50 \mathrm{kGy}$ irradiation compared with controls.

Because research has supported the hypothesis that gamma radiation-induced allograft damage is caused, in part, by free radical attack on the molecular structure of the collagen, ${ }^{51,52}$ a number of radioprotectants have been used to eliminate or decrease the deleterious effects of irradiation. Grieb and colleagues ${ }^{53}$ reported that a radioprotective "cocktail" solution, which included propylene glycol, dimethyl sulfoxide (DMSO), mannitol, and trehalose, was successful in protecting mechanical properties of human semitendinosus tendon at $50 \mathrm{kGy}$ under regulated conditions. Akkus and colleagues ${ }^{51}$ reported that the use of another free radical scavenger, thiourea, resulted in increased toughness at $36 \mathrm{kGy}$ in bone allografts. Seto and colleagues ${ }^{49}$ used crosslinkers, including 1-ethyl-3-(3-dimethylaminopropyl) carbodiimide (EDC) and glucose to add exogenous crosslinks to collagen and compared their effects to those of free radical scavengers (mannitol, ascorbate, and riboflavin) in rabbit tendons. Both treatments protected mechanical properties at $25 \mathrm{kGy}$, but at $50 \mathrm{kGy}$ crosslinkers were superior. The strength, modulus of elasticity, toughness, and strain of glucose-treated tendon, either gamma or electron-beam irradiated at $25 \mathrm{kGy}$, were close to those of native tendon. Kattaya and colleagues ${ }^{54}$ noted that along with the beneficial effects of radioprotectants there is also the potential of radioprotection of pathogenic organisms and that the ideal radioprotectant should protect graft integrity without compromising sterility.

\section{Combined methods of sterilization}

Combining lower doses of irradiation (1-3.5 Mrad, 10-35 kGy) with other processing techniques, such as antibiotic soaks, is probably the most commonly used method today.

Several companies have proprietary processes for sterilization that each claims will provide a disease-free graft. Cryolife, Inc. (Kennesaw, GA) uses a slow freezing process along with DMSO or glycerol for cryopreservation of grafts. After swab culturing and desiccation, the grafts are treated for an extended period of time with an antimicrobial solution. No secondary sterilization method is used.

BioCleanse (Regeneration Technologies, Inc., Alachua, FL) is a low-temperature chemical sterilization method that is claimed to penetrate the tissue and eliminate endogenous contamination. The process permeates the inner matrix of tissue with liquid sterilants, such as hydrogen peroxide and isopropyl alcohol, followed by pressure variations to drive the sterilants in and out of the tissue. Soft-tissue grafts (bone-tendon-bone, fascia, tendons, and menisci) are treated with this method. Studies have shown that the BioCleanse process does not appear to affect the mechanical properties of BPTB grafts ${ }^{55}$ or anterior tibial tendon grafts. ${ }^{56}$ 
Allowash (Lifenet, Virginia Beach, VA) uses ultrasonics, centrifugation, and negative pressure in combination with reagents, including biologic detergents, alcohols, and hydrogen peroxide. This process claims to increase solubilization and remove lipids, blood, and marrow cells that can act as reservoirs for potential bacterial, fungal, and viral agents. BPTB allografts are terminally sterilized using 13 to $18 \mathrm{kGy}$ of radiation.

The Tutoplast process (RTI Biologics, Alachua, FL) also uses an ultrasonic acetone bath to remove lipids, followed by a series of alternating hyperosmotic saline and deionized water baths to destroy bacteria. An oxidative treatment with hydrogen peroxide is then used to eliminate soluble proteins and destroy nonenveloped viruses and bacterial spores. A final acetone wash is done to ensure that any residual prions are removed and enveloped viruses are inactivated and to dehydrate the tissue; this is followed by vacuum extraction, which allows storage at room temperature. Terminal sterilization is done with low-dose gamma irradiation.

The Clearant Process (Clearant, Inc., Los Angeles, CA) treats tissue with high doses of radiation ( $50 \mathrm{kGy}$ ), which is 2 to 4 times the dose recommended to avoid tissue damage but claims to avoid this by freezing the sample, extracting the water, and adding stabilizers and free radical scavengers. After the tissue is frozen and the water extracted, DMSO and propylene glycol are added as pretreatment radioprotectants. ${ }^{53}$

NovaSterilis (Lansing, NY) developed a technique of sterilization that uses supercritical carbon dioxide at low temperatures and relatively low pressures to induce transient acidification, which is lethal to viruses and bacteria. Although tissue penetration appears to be good with this method, data concerning the effects on the mechanical properties of allografts are limited at this time.

The Musculoskeletal Transplant Foundation (MTF, Edison, NJ), a non-profit organization, also uses a series of chemicals, including nonionic detergents, hydrogen peroxide, and alcohol, to treat most cortical and cancellous grafts, without terminal sterilization with irradiation. This process has been demonstrated to maintain osteoconductivity for up to 1 hour; compressive strength, impact strength, and shear strength are reported to be unaffected by the cleaning procedure. ${ }^{57}$ BPTB and other soft-tissue allografts are treated with an antibiotic "cocktail" of gentamicin, amphotericin B, and Primaxin (imipenem and cilastatin). The antibiotics are washed out at the completion of processing to nondetectable levels. Low-dose gamma irradiation (12-18 kGy) is used for tissue that is found to have a bioburden (the number of contaminating organisms on a given amount of material before sterilization) greater than what could be sterilized by the antibiotic cocktail.

\section{STORAGE OF PROCESSED ALLOGRAFT TISSUE}

Once the allograft tissue has been processed, it must be preserved and stored until needed. Articular cartilage allografts may be used as "fresh" grafts, within 24 days of donor death, but most other allograft tissue is fresh-frozen, freeze-dried, or cryopreserved.

Fresh-freezing or deep-freezing is the simplest and most widely used storage method for ligament and meniscal tissue. After sterile tissue harvest, the tissue is cultured and then frozen while serologic tests are done; the tissue is then soaked in an antibiotic solution, packaged, and frozen. The AATB requires storage at a temperature of at least $-40^{\circ} \mathrm{C}$, but most tissue banks keep allografts at $-70^{\circ} \mathrm{C}$ to $-80^{\circ} \mathrm{C}$, which allows storage for 3 to 5 years; $;^{4,20}$ at a temperature near $-196^{\circ} \mathrm{C}$, grafts can be preserved for as long as 10 years. $^{4}$

Freeze-drying or lypophilization (residual moisture content of less than $5 \%$ ) destroys all cells within the tissue but has the advantage of allowing vacuum-packed storage at 
room temperature for 3 to 5 years. This method is not often used for sports medicine procedures in the United States because the process can degrade the mechanical properties of soft-tissue allografts. ${ }^{3}$ A disadvantage is the need for a minimum of 30 minutes of rehydration of the graft before use, especially if a bone block is attached to the soft tissue. Freeze-drying alters the material properties of collagen but has not been shown to have a clinical effect. ${ }^{20}$ One study ${ }^{58}$ noted a significant association between the failure of freeze-dried allografts used for ACL reconstruction and the time from procurement to implantation, suggesting that the shelf life of freeze-dried tissues is limited. Another study ${ }^{59}$ found that the ultimate strength of cancellous bone was reduced by $19 \%$ and stiffness by $20 \%$ in rehydrated lypophilized grafts, suggesting that the mechanical properties of lypophilized BPTB grafts may be inferior to those of fresh-frozen allografts.

Cryopreservation is a process by which the tissue undergoes controlled-rate freezing to $-135^{\circ} \mathrm{C}$ while cellular water is extracted by glycerol and DMSO. Packed in a cryoprotectant solution, the graft has a shelf life of 10 years, and up to $80 \%$ of cells can remain viable..$^{4,9,20}$

\section{SUMMARY}

No sterilization techniques have been definitively proven to be more effective than others, and their biomechanical and biological effects on allograft tissue remain largely unknown. Despite recent highly publicized occurrences of infection from allografts, however, the current risk of an allograft infection appears to be much less than the risk of infection surrounding the surgical procedure itself..$^{5,9}$ Most of these incidents involved questionable practices, violations of FDA regulations, and even alleged illegal activities by recovery agents. ${ }^{13,15,24}$ According to a report from the AATB covering data from 2003 and 2004, of 192 reports of suspected allograft-related infections, $42 \%$ involved soft-tissue grafts and $37 \%$ involved bone grafts, with an overall incidence of $0.014 \%$; $59 \%$ involved orthopedic sports medicine procedures. ${ }^{9}$ The American Academy of Orthopaedic Surgeons (AAOS) recommends that surgeons choose tissue provided by an AATB-member tissue bank and that they be familiar with the different sterilization processes used for allografts. ${ }^{60,61}$ With appropriate donor screening, improved donor testing, including NAT, and adherence to AATB standards, the risk of disease transmission or infections can be eliminated or substantially decreased.

\section{REFERENCES}

1. Harner CD, Olson E, Irrgang JJ, et al. Allograft versus autograft anterior cruciate ligament reconstruction: 3- to 5-year outcome. Clin Orthop Relat Res 1996;324: 134-44.

2. Lephart SM, Kocher MS, Harner CD, et al. Quadriceps strength and functional capacity after anterior cruciate ligament reconstruction. Patellar tendon autograft versus allograft. Am J Sports Med 1993;21:738-43.

3. Saddemi SR, Frogameni AD, Fenton PJ, et al. Comparison of perioperative morbidity of anterior cruciate ligament autografts versus allografts. Arthroscopy 1993;9:519-24.

4. Shelton WR. Arthroscopic allograft surgery of the knee and shoulder: indications, techniques, and risks. Arthroscopy 2003;19(Suppl 1):67-9.

5. Vangsness CT Jr. How safe are soft-tissue allografts? AAOS Now August 2007; Available at: http://www.aaos.org/news/bulletin/aug07/clinical1.asp. Accessed July 25, 2008. 
6. Saurez LS, Richmond JC. Overview of procurement, processing, and sterilization of soft tissue allografts for sports medicine. Sports Med Arthrosc 2007; 15:106-13.

7. Robertson $A$. Current trends in the use of tendon allografts in orthopaedic surgery. J Bone Joint Surg Br 2006;88B:988-92.

8. 2006 AOSSM Orthopaedic Surgical Procedure Survey on Allografts. Napier (IL): Leever Research Services; 2006. Accessed July 25, 2008.

9. McAllister DR, Joyce MJ, Mann BJ, et al. Allograft update: the current status of tissue regulation, procurement, processing, and sterilization. Am J Sports Med 2007;35:2148-58.

10. Branam BR, Johnson DL. Allografts in knee surgery. Orthopedics 2007;30:925-9.

11. Rinn JA, Harner CD. The use of musculoskeletal allograft tissue in knee surgery. Arthroscopy 2003;19(Suppl 1):51-66.

12. Patel R, Trampuz A. Infections transmitted through musculoskeletal tissue allografts. N Engl J Med 2004;350:2544-6.

13. Centers for Disease Control and Prevention. Update: allograft associated bacterial infections-United States, 2002. MMWR Morb Mortal Wkly Rep 2002;51:207-10.

14. Centers for Disease Control and Prevention. Invasive Streptococcus pyogenes after allograft implantation, Colorado, 2003. MMWR Morb Mortal Wkly Rep 2003;52:1173-6.

15. MSNBC. Body parts snatching case sparks fears. Available at: http://www. msnbc.msn.com/id/11461578. Accessed February 21, 2006.

16. Kainer MA, Linden JV, Whaley DN, et al. Clostridium infections associated with musculoskeletal-tissue allografts. N Engl J Med 2004;350:2564-71 [Errata in N Engl J Med 2004; 351:397-8 and 351:2025].

17. Dodd RY, Notari EP 4th, Stramer SL. Current prevalence and incidence of infectious disease markers and estimated window-period risk in the American Red Cross blood donor population. Transfusion 2002;42:975-9.

18. Rigney PR. Implementation of nucleic acid testing (NAT). AATB Bulletin No. 04-42. Available at: http://www.aatb.org. September 2004. Accessed July 25, 2008.

19. Gocke DJ. Tissue donor selection and safety. Clin Orthop Relat Res 2005;435: 17-21.

20. Vangsness CT Jr, Wagner PP, Moore TM, et al. Overview of safety issues concerning the preparation and processing of soft-tissue allografts. Arthroscopy 2006;22: 1351-8.

21. Zou S, Dodd RY, Stramer SL, et al. Tissue Safety Study Group. Probability of viremia with HBV, HCV, HIV, and HTLV among tissue donors in the United States. N Engl J Med 2004;351:751-9.

22. Centers for Disease Control and Prevention. Update: Creutzfeldt-Jakob disease associated with cadaveric dura mater grafts - Japan, 1979-2003. MMWR Morb Mortal Wkly Rep 2003;52:1179-81.

23. Office of Inspector General. Oversight of tissue banking. January 2001. Available at: www.fda.gov/ohrms/dockets/ac/01/briefing/3736b_01.pdf. Accessed July 25, 2008.

24. US Food and Drug Administration. Guidance for industry: validation of procedures for processing of human tissues intended for transplantation. Available at: http://www.fda.gov/cber/tissue/docs.htm. March 2002. Accessed July 25, 2008.

25. US Food and Drug Administration. Tissue related documents. Available at: http:// www.fda.gov/cber/tissue/docs.htm. October 30, 2006. Accessed July 25, 2008.

26. Crawford C, Kainer M, Jernigan D, et al. Investigation of postoperative allograftassociated infections in patients who underwent musculoskeletal allograft implantation. Clin Infect Dis 2005;41:195-200. 
27. Veen MR, Bloem RM, Petit PL. Sensitivity and negative predictive value of swab cultures in musculoskeletal allograft procurement. Clin Orthop Relat Res 1994; 300:259-63.

28. American Association of Tissue Banks: standards for tissue banking. MacLean (VA): American Association of Tissue Banks; October, 2006.

29. Fideler BM, Vangsness CT Jr, Moore T, et al. Effects of gamma irradiation on the human immunodeficiency virus. A study in frozen human bone-patellar ligamentbone grafts obtained from infected cadavers. J Bone Joint Surg Am 1994;76: 1032-5.

30. Lemaire R, Masson JB. Risk of transmission of blood-borne viral infection in orthopaedic and trauma surgery. J Bone Joint Surg Br 2000;82B:313-23.

31. Prolo DJ, Pedrotti PW, White DH. Ethylene oxide sterilization of bone, dura mater, and fascia lata for human transplantation. Neurosurgery 1980;6:529-39.

32. Jackson DW, Windler GE, Simon TM. Intraarticular reaction associated with the use of freeze-dried, ethylene oxide-sterilized bone-patella tendon-bone allografts in the reconstruction of the anterior cruciate ligament. Am J Sports Med 1990;18:1-11.

33. Roberts TS, Drez D Jr, McCarthy W, et al. Anterior cruciate ligament reconstruction using freeze-dried, ethylene oxide-sterilized, bone-patellar tendon-bone allografts. Two year results in thirty-six patients. Am J Sports Med 1991;19:35-41.

34. Steenland K, Stayner L, Greife A, et al. Mortality among workers exposed to ethylene oxide. N Engl J Med 1991;324:1402-7.

35. Smith CW, Young IS, Kearney JN. Mechanical properties of tendons: changes with sterilization and preservation. J Biomech Eng 1996;118:56-61.

36. FDA Workshop: processing of orthopedic, cardiovascular and skin allografts. Bethesda (MD), October 12, 2007. Available at: http://www.fda.gov/cber/ minutes/allog101207t.htm.

37. Pruss A, Bauman B, Seibold M, et al. Validation of the sterilization procedure of allogeneic avital bone transplants using peracetic acid-ethanol. Biologicals 2001;29:59-66.

38. Pruss A, Gobel UB, Pauli G, et al. Peracetic acid-ethanol treatment of allogeneic avital bone tissue transplants - a reliable sterilization method. Ann Transplant 2003;8:34-42.

39. Scheffler SU, Scherler J, Pruss A, et al. Biomechanical comparison of human bone-patellar tendon-bone grafts after sterilization with peracetic acid ethanol. Cell Tissue Bank 2005;6:109-15.

40. Scheffler SU, Gonnermann J, Kamp J, et al. Remodeling of ACL allografts is inhibited by peracetic acid sterilization. Clin Orthop Relat Res [Epub ahead of print].

41. Campbell DG, Li P. Sterilization of HIV with irradiation: relevance to infected bone allografts. Aust N Z J Surg 1999;69:517-21.

42. Mitchell EJ, Stawarz AM, Kayacan $R$, et al. The effect of gamma radiation sterilization on the fatigue crack propagation resistance of human cortical bone. J Bone Joint Surg Am 2004;86:2648-57.

43. Moroz TE, Lin EL, Summit MC, et al. Biomechanical analysis of allograft bone treated with a novel tissue sterilization process. Spine J 2006;6:34-9.

44. Nguyen $\mathrm{H}$, Morgan DA, Forwood MR. Sterilization of allograft bone: is $25 \mathrm{kGy}$ the gold standard for gamma irradiation? Cell Tissue Bank 2007;8:81-91.

45. Schwartz HE, Matava MJ, Proch FS, et al. The effect of gamma irradiation on anterior cruciate ligament allograft biomechanical and biochemical properties in the caprine model at time zero and at 6 months after surgery. Am J Sports Med 2006; 34:1747-55. 
46. Curran AR, Adams DJ, Gill JL, et al. The biomechanical effects of low-dose irradiation on bone-patellar tendon-bone allografts. Am J Sports Med 2004;32: 1131-5.

47. Balsly CR, Cotter AT, Williams LA, et al. Effect of low dose and moderate dose gamma irradiation on the mechanical properties of bone and soft tissue allografts. Cell Tissue Bank [Epub ahead of print].

48. Dziedzic-Goclawska A, Kaminski A, Uhrynowska-Tyszkiewicz I, et al. Irradiation as a safety procedure in tissue banking. Cell Tissue Bank 2005;6:201-19.

49. Seto A, Gatt Jr CJ, Dunn MG. Radioprotection of tendon tissue via crosslinking and free radical scavenging. Clin Orthop Relat Res [Epub ahead of print].

50. Pruss A, Keshlaf S, Smith M, et al. A novel sterilization process based on electron beam radiation does not impair the mechanical properties of soft tissue allografts. Available at: http://www.aatb.org/files/2007abstract19.pdf. Accessed July 25, 2008.

51. Akkus O, Belaney RM, Das P. Free radial scavenging alleviates the biomechanical impairment of gamma radiation sterilized bone tissue. J Orthop Res 2005; 23:838-45.

52. Hawkins CL, Davies MJ. Oxidative damage to collagen and related substrates by metal ion/hydrogen peroxide systems: random attack or site-specific damage? Biochim Biophys Acta 1997;1360:84-96.

53. Grieb TA, Forng RY, Bogdansky S, et al. High-dose gamma irradiation for soft tissue allografts: high margin of safety with biomechanical integrity. J Orthop Res 2006;24:1011-8.

54. Kattaya SA, Akkus O, Slama J. Radioprotectant and radiosensitizer effects on sterility of gamma-irradiated bone. Clin Orthop Relat Res 2008 May [Epub ahead of print].

55. Jones DB, Huddleston PM, Zobitz ME, et al. Mechanical properties of patellar tendon allografts subjected to chemical sterilization. Arthroscopy 2007;23:400-4.

56. Schimizzi A, Wedemeyer M, Odell $T$, et al. Effects of a novel sterilization process on soft tissue mechanical properties for anterior cruciate ligament allografts. Am J Sports Med 2007;35:612-6.

57. DePaula CA, Truncale KG, Gertzman AA, et al. Effects of hydrogen peroxide clearing procedures on bone graft osteoconductivity and mechanical properties. Cell Tissue Bank 2005;6:287-98.

58. Sterling JC, Meyers MC, Calvo RD. Allograft failure in cruciate ligament reconstruction. Follow-up evaluation of eighteen patients. Am J Sports Med 1995;23: 173-8.

59. Cornu O, Banse X, Docquier PL, et al. Effect of freeze-drying and gamma irradiation on the mechanical properties of human cancellous bone. J Orthop Res 2000;18:426-31.

60. American Academy of Orthopaedic Surgeons. Advisory Statement \#1011: use of musculoskeletal tissue allografts. Available at: http://www.aaos.org/about/ papers/advistmt/1011.asp. Accessed July 25, 2008.

61. Joyce MJ. Safety and FDA regulations for musculoskeletal allografts: perspective of an orthopaedic surgeon. Clin Orthop Relat Res 2005;435:22-30. 